\title{
Success Of An Organization is a Result Of Employees Performance
}

\author{
Muhammad Nabeel Siddiqui \\ Arabian Gulf Manufacturers. Co. Ltd \\ Jeddah- Saudi Arabia \\ muhammadnabeel19@gmail.com
}

\begin{abstract}
The aim of this study is to determine that success of a company is because of its employees' performance. Organizations must also ensure that there employees' are highly satisfied with their jobs. Although, there are various factors that effects satisfaction, one of them is training. Training is basically improvement in knowledge, skills and abilities of an employee on continual basis. This increases the competency level of employee as well as ensures that they are highly employable. Flexible working shifts can lift organization's productivity higher. Appreciation on every accomplishment, produce new opportunities to practice creativity and competency. This will lead to higher satisfaction. The researcher has chosen quantitative research methodology. Quantitative research methodology gives concrete information through data collection and statistical analysis. Performance of employees should be evaluated to keep the productivity increasing. The process of employee development is very essential and should be effectively implemented. The best way to keep employee retained in the organization is to keep him motivated.
\end{abstract}

Keywords: Organization success, Employee performance, Job satisfaction, Performance and success.

\section{Background of the study:}

\section{INTRODUCTION}

In today's world of competition, it is believed that teams are essential part of work performance and increased productivity. In this regard, Hackman (1990) believed that, 'practically everybody has been a member of performing group at any time if he has worked in the organization' (p.2). Regardless of near omnipresence of teams according to the organizational structure, there is still absence of accuracy about the attributes of high performing teams, and even lack of the experience of members of those teams.

Almost every organization battles to implement the use of team effectively (Katzenbach and Smith, 1994). Effective implementation of teams is even more challenging when it comes to multicultural organizations. It can be multicultural either by being operated in a country with different cultures or by operating in more than one country (Adler, 1983). Adler further added, being multicultural or operating in different countries increases the complexity for an organization. It requires more mature integrated mechanisms to follow than essential for a domestic organization following one culture. Apud, Johnson, and Lenartowizc (2006) quoted absence of skills to deal with issues regarding multicultural organizations as main reason of failure of global organizations. 
More specifically quoted issues with communication and lack of understanding of communication across different cultures as barrier to success. Organizations with more experience operating internationally do not replicate greater effectiveness in handling issues regarding culture. Kim (1999) indicated that regardless of organization's expansion of international business, there are always some cultural barriers that can undermine organizational success.

Kim further added that, regardless of challenges, the management and effective use of cross cultural teams will be essential requirement for every organization in forthcoming time.

Lastly, Sparrow (1998) most of the challenges that organizations have with people and teams return from managing problems and worker expectations from a mono-cultural (almost always Western) perspective. Work related, the subject of culture has been taken from perspective of national (Hofstede, 1980), regional (Javidan, Dorfman, de Lugue, \& House, 2006), and organizational (Schein, 1992).

\section{Problem Statement:}

Less information about how much impacting effective policies and procedures can be when implemented in multicultural organizations. It was found that the employees were scared of introducing new ways to improve operations and even of suggesting or providing new ideas that's because last leadership introduced fear within the organization.

Previous administration decreased the self esteem of employees to the extent where they were reluctant to propose any productive suggestion due to the fear of revenge. This also led the organization to high turnover and made it extremely difficult for organization to deal with it.

\section{Purpose of Study:}

The purpose of the study is to conclude that employee performance can lead to the organization to success in Saudi Arabia.

\section{Aims and Objectives of the Study}

The objectives include:

- Examine how team management is important in an organization in Saudi Arabia.

- Indicate how diversified management is impacting organizations in Saudi Arabia.

- Explain the challenges managers face while managing diversified teams.

\section{Research Questions}

Research question include:

- What are the factors that influence more positive interaction among Saudi managers?

- How continual improvement in performance and organizational commitment cause motivation for managers in Saudi?

- How motivation plays its role in increased job satisfaction for employees in Saudi?

○ What are the challenges faced by managers while managing diversified teams?

○ What are the challenges faced by managers while they lead a multicultural team?

\section{Rationale of the Study}

The world has become a global world. Organizations are moving towards globalization by moving towards exchange of technology, economic, politics and culture, which is result of latest communication, transportation and open border links connecting international trade and finance across countries. Highly interconnected businesses moving towards expansion of 
business, more effective communication and joint ventures as well as cultural mergers has caused changes faced by Saudi business community (Shippy, 2008).

\section{Ethical Concerns}

The protection of human subject will be on priority. Several strategies will be followed strictly in this regard. No data will be revealed more than the interviewee wished for. The responses given by participants will also be kept confidential. Participants will be explained about how and why the study is being conducted by the researcher. Anonymity and secrecy will be ensured by changing the names of participants. The access to participants' response and their names will be only to researcher.

The participant will have all the rights to withdraw during interview or answering questionnaire. The consent form will be read and signed before collecting the data. High secrecy and confidentiality will be ensured.

\section{Limitations of the Study}

Ideally the sample of the research should include employees of different companies operating in Saudi as main focus is on teamwork. To get more accurate responses in this perspective the population of this particular research will include managers who are leading different organizations in Saudi Arabia.

Nevertheless, the access is limited in reaching hotel managers, financial resources, as well as time. This limits the sample size to managers of multinational giant firms in Saudi Arabia only. Whole population may or may not get the responses and outcome of this study. The study also contains literature review from different fields such as human resource management, international business and others related to team work.

\section{Hypothesis:}

$\bigcirc \mathrm{H}_{0}$ : Success of an Organization is not a result of Employees Performance

$\circ \mathrm{H}_{\mathrm{A}}$ : Success of an Organization is a result of Employees Performance

\section{Theoretical Framework of the Study}

\section{LITERATURE REVIEW}

Bird $(2002,33)$ quoted the ethical behaviour of leaders, what they may or may not do, their influence and the expectations from leaders vary from country to country due to the cultural forces of that particular country or region.

The theoretical framework is constructed on the basis of cultural characteristics developed by (Bhagat, 1996, 89) transformative learning theory on culture adjustment, and the leadership challenge theory of Kouzes and Posner (2001). The five basic dimensions identified by Greert Hosfstede (Robbins, 2003) are referenced mostly to analyze variations of cultures.

\section{Employee Performance}

To maintain and manage performance of each employee, organizations should use certain procedures to follow and continuously monitor the performances. These performance indicators will help the organizations to measure how efficiently and effectively the goals are being met. There should be a well managed comprehensive system that will lead each employee and manager to highest level of performing (Beauchamp, Bowie, 1983, 32).

As many practices have changed, firms now follow merit-based pay and some follow pay-forperformance model. To maintain the employee perform at its higher level firms must keep 
them motivated. In this regard firms evaluate and reward their performances accordingly. (Goodin, 2007, 24) highlighted formal management process to evaluate the degree of employee's performance is performance appraisals. The quality of employee's performance is evaluated through discussion with his/her supervisor about his/her performance as well as the strength and weaknesses he posses along with the improvements to develop his/her working skills (Finnegan, Schofield, Swift, 1996, 47). While this discussion the responses are noted on history, career development, job standards and organizational goals to make people more accountable.

\section{Relationship between Team Attributes and Team Performance}

It is essential to understand that teamwork is not only related to teams. It can be studied in a variety of attitudes being shown by the person in a committee or group as well (Jackson, 2002, 71). For a person having teamwork skills may or may not be part of a team. A group working towards some common goal is referred as team but it is not necessary that each team has team working skills. There may be resistances among the group and they may not go well with each other. While team work has benefit of sense of responsibility divided on each member equally in a shared task (Higgins, 1994, 74). Another view is about cash based incentives although some researchers argue that this will create some behavioural issues among employees as well. Employees may follow unethical behaviour to get lion's share in the pay-based motivation. Some others argue that reward can not result in motivation. It is just the matter of behaviour and conditioning which lead employees act in certain way.

\section{Diversity Management}

Diversification has now become an essential part of organizations in Saudi. Companies now have realised the importance of inclusive motivation management. Different motivational strategies to fit the approved program and the environment meeting the diverse needs of the firm are followed by managers in regard to the diversity of employees in the firm (Likert, 1967, 85). Every employee can not be motivated by providing same reward because of their different levels of motivation. Maslow's hierarchy is therefore the best way to asses and fulfil each employee's needs and improve him/her accordingly (Leone, 2007, 93).

\section{Culture and its Characteristics}

Any particular group of people following certain same characteristics makes a culture, quoted by (Baldwin, 1988, 63) in their research. However, another definition of culture is proposed by (Ali, 1995, 85), he said "Culture consists in patterned ways of thinking, feeling and reacting, acquired and transmitted mainly by symbols, constituting the distinctive achievements of human group, including their embodiments in artefacts; the essential core of culture consists of traditional (i.e., historically derived and selected) ideas and especially their attached values." Kopp, $(2001,30)$ defines culture as "a way of life of a group of people, the configuration of all of the more or less stereotyped patterns of learned behaviour, which is handed down from one generation to the next through the means of language and imitation."

\section{Research Design}

\section{METHODOLOGY}

The researcher has chosen quantitative research methodology. Quantitative research methodology gives concrete information through data collection and statistical analysis. This approach uses models, theories and hypothesis of mathematics for the measurement of empirical associations present in natural phenomena. Large and random samples are used in this approach to gather data (Saunders, 2007, p.48). Reliable and valid tools are used to collect accurate data and is analysed through application of statistical tools. This approach is based on 
numerical data which gives the research appropriate findings. The results and findings are based on application of statistical tools and techniques to get accurate results in this study (Saunders, 2007, p.48).

\section{Sampling}

Researcher has used random sampling for this study. The reason to this is to draw inference about the population. The reason to this is if the sample is non random, there are chances that sample can be biased (Saunders, 2007, p.48). Even in non random sampling it is very difficult to draw inference. The sample is drawn from the participants on frame which should exactly replicate the population of interest in Jeddah - Saudi Arabia . Otherwise the difference between individuals on the frame and in population will lead to coverage of error (Creswell, 2009, p. 86).

\section{Sample of Participants}

The sample consists of 100 participants. It includes employees working at different positions including supervisors from different organizations operating in Jeddah. The number of male and female participants in this study was 75 and 25 respectively, ranging from 25 to 60 years of years. Employees' perception about their respective firm's support was given appropriate consideration by the researcher to measure motivation and satisfaction among team members (Bennett, 2004, p. 21).

\section{Instrument}

Questionnaire is used as a data collecting tool in this study. Questionnaire is easy-to-use tool to collect data. Questionnaire includes two types of questions, open-ended and close-ended. This questionnaire also included demographic related questions. Questionnaires were sent to employees through email and were asked to submit their responses through same medium.

\section{Data Analysis}

Data analysis is the most challenging part of any research. All the results and findings are based on data analysis. After getting responses from participants the researcher used statistical tools to analyse data. Descriptive and inferential statistic techniques were used. Furthermore, regression analysis was used to check the relationship between independent and dependent variables.

\section{Validity and Reliability}

Bennett (2004, p. 21) defined validity as the degree to which it measures what is supposed to be measured. The two main types of validity are content validity and construct validity. Reliability is defined as when two or more measures can measure the same variable. Mostly used measurement for reliability in statistically analysis is Cronbach Alpha Coefficient.

\section{Discussion}

\section{DISCUSSION AND ANALYSIS}

Every organization in today's world of competition wants their employees to get to higher level of performance. Through the studies it is concluded that employee performance is function of employee satisfaction. Both of factors are interrelated. The higher level of satisfaction an employee feels, the better he/she will perform. Motivation also plays a very important role in moving employees' satisfaction to higher level. It also increases the productivity of employees in organizations in Saudi Arabia (Spector, 2006, p. 49).

\section{Improving performance and commitment in the workplace}

The degree of contentment that an employee has with its job is his/her job satisfaction. The 
feeling of achievement related to his/her job is directly linked to their job satisfaction. Job satisfaction can be effected by number of factors including the organizational relationships among employees as well as with the boss, the environment etc (Spector, 2006, p. 49).

According to study conducted by Harvard group of professionals in the year 1998 stated that if the employee is motivated he/she will have feeling of higher recognition and more linked to accomplishment of organizational goals which leads to efficient and effective manner of job performance. Job satisfaction is also effected by the motivation of an employee which leads to the feeling of self actualization along with other factors being fulfilled.

\section{Job design for job satisfaction}

Job design includes job rotation, job enrichment as well as job reengineering. It boosts the satisfaction to higher level. Higher job satisfaction can lead to higher performance improvements. The management style a manager or supervisor follows has also a very large impact on how satisfied the employees are. Other than this the empowerment and job allotted to an employee also plays an important role in his/her satisfaction. Job design is shaped by keeping all these factors in mind. Organizations hardly give importance to job satisfaction in success of the firm (Lapierre \& Hackett, 2007, p. 539). If organization's competitive advantage is their human resource, it is unbeatable in this competitive world.

\section{Motivation for job satisfaction}

Motivation can be defined as a person's intrinsic willingness to achieve any particular goal or task. People with higher motivation tend to have higher desire and energy to achieve goals. That means the more motivated an employee is, the more energized and committed he/she will be with his/her job. Employee can be less motivated if organization fails to communicate how important they are for their organizations. Employees feel extremely motivated if they come to know how their performance is being evaluated by the management. It is keen responsibility of management to keep employee updated with his/her performance evaluation. The better feedback employee gets, the more satisfied he/she will be. In other case it will create ambiguity and will lead employees to dropped performance (Judge \& Thoresen, 2001, p. 376).

\section{Survey Analysis}

\begin{tabular}{|l|l|r|r|r|r|}
\hline \multicolumn{7}{|c|}{ Table 1: Question 1 } \\
\hline \multirow{3}{*}{ Valid } & & F & \multicolumn{1}{c|}{$\%$} & Valid \% & Cumulative \% \\
\cline { 2 - 6 } & Male & 75 & 75.0 & 75 & 100.0 \\
\cline { 2 - 6 } & Female & 25 & 25.0 & 25 & 100.0 \\
\cline { 2 - 6 } & Total & 100 & 100.0 & 100.0 & \\
\hline
\end{tabular}

The trial for this research consists of 100 Saudi individuals, employees of famous organizations in Jeddah. The numbers of male and female participants were 75:25 ratio male employees were 75 and female were 25.

\begin{tabular}{|l|l|l|l|l|l|}
\hline \multicolumn{5}{|c|}{ Table 2: Question 2 } \\
\hline \multirow{3}{*}{ Valid } & & $\mathrm{F}$ & $\%$ & Valid \% & Cumulative \% \\
\cline { 2 - 6 } & $21-30$ & 26 & 27.0 & 27.0 & 27.0 \\
\cline { 2 - 6 } & $31-40$ & 24 & 23.0 & 23.0 & 50.0 \\
\cline { 2 - 6 } & $41-50$ & 20 & 21.0 & 21.0 & 71.0 \\
\cline { 2 - 6 } & $51-60$ & 30 & 29.0 & 29.0 & 100.0 \\
\cline { 2 - 6 } & Total & 100 & 100.0 & 100.0 & \\
\hline
\end{tabular}


Q2

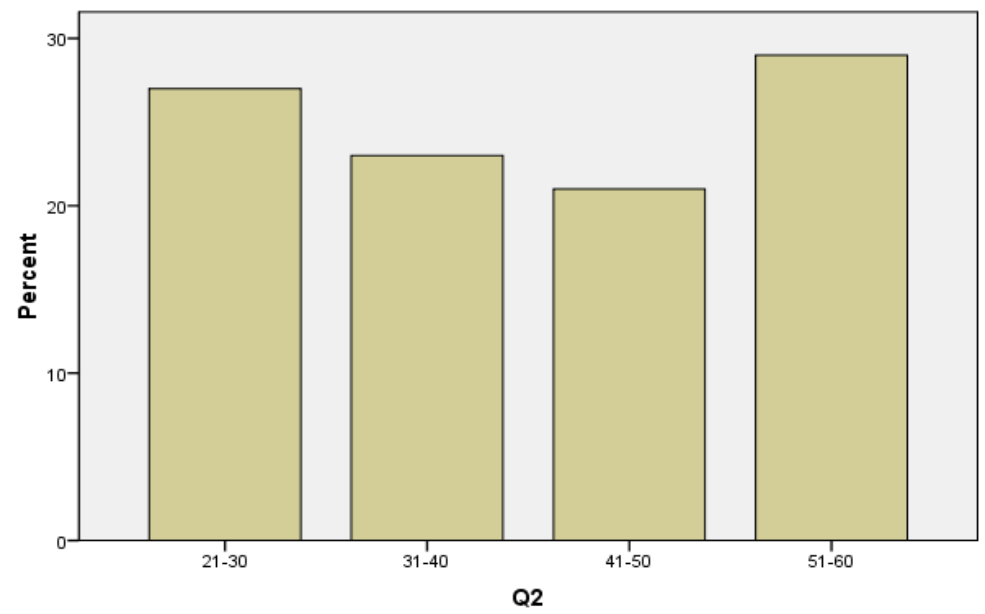

The ages of the employees range from 25 years to 60 years. Employees working in different positions and capacities, including supervisors were eligible to participate in this research. While collecting the data, the researcher gives due consideration to the employee's perception about their organisation's support so that it gives an appropriate measure of motivation and satisfaction between the team members.

\begin{tabular}{|l|l|l|l|l|l|}
\hline \multicolumn{5}{|c|}{ Table 3: Question 3 } \\
\hline \multirow{3}{*}{ Valid } & & F & $\%$ & Valid \% & Cumulative \% \\
\cline { 2 - 6 } & Yes & 52 & 52.0 & 52.0 & 52.0 \\
\cline { 2 - 6 } & No & 48 & 48.0 & 48.0 & 100.0 \\
\cline { 2 - 6 } & Total & 100 & 100.0 & 100.0 & \\
\hline
\end{tabular}

Q3

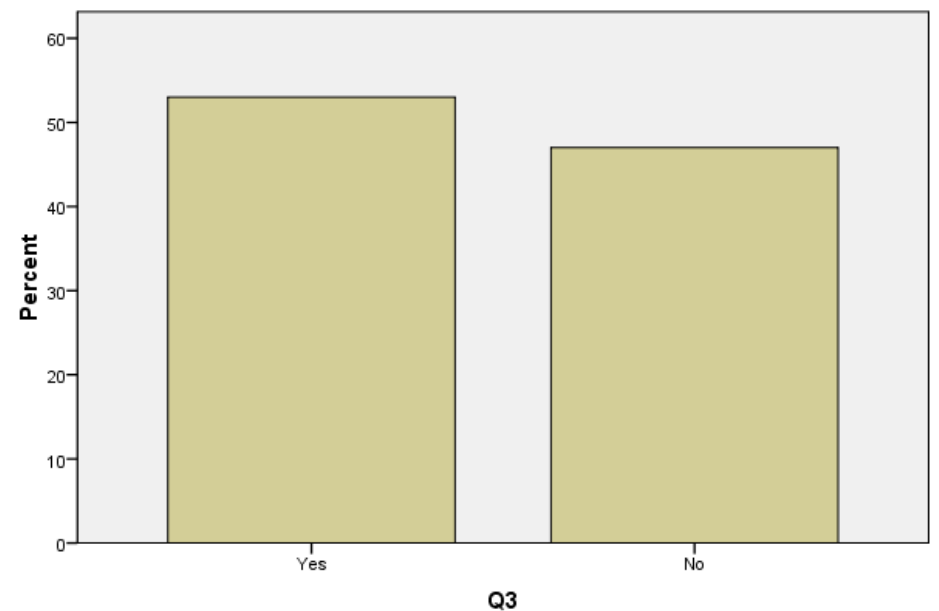

In whole, sample respondents $53 \%$ respondents are employed in retail sector firm and 47 respondents are employed outside the retail sector firm.

\begin{tabular}{|l|l|l|l|l|l|}
\hline \multicolumn{5}{|c|}{ Table 4: Question 4 } \\
\hline \multirow{3}{*}{ Valid } & & F & $\%$ & Valid \% & Cumulative \% \\
\cline { 2 - 6 } & Yes & 39 & 39.0 & 39.0 & 39.0 \\
\cline { 2 - 6 } & No & 61 & 61.0 & 61.0 & 100.0 \\
\cline { 2 - 6 } & Total & 100 & 100.0 & 100.0 & \\
\hline
\end{tabular}


Q4

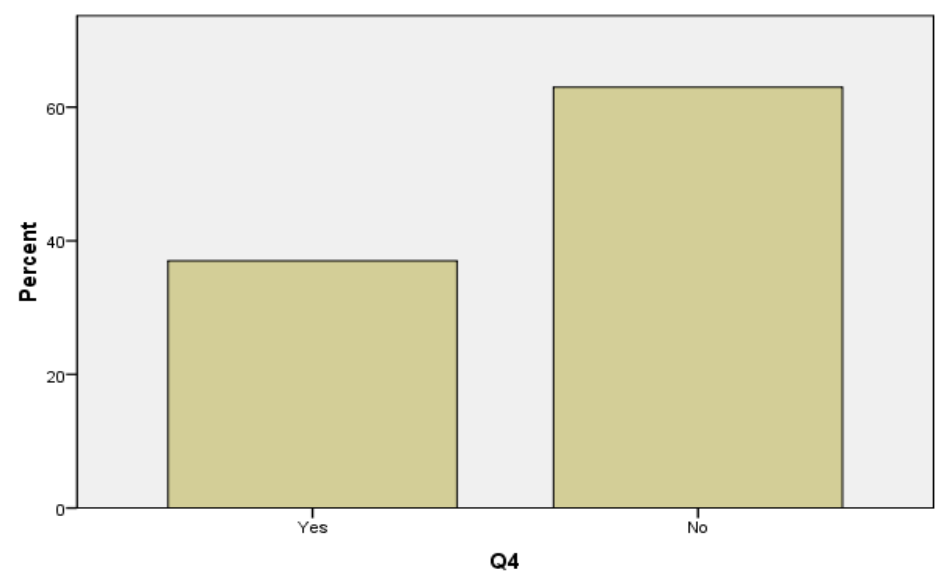

In whole, sample respondents $39 \%$ respondents pleased with the working environment and $61 \%$ respondents are not pleased with the working environment.

\begin{tabular}{|l|l|l|l|l|l|}
\hline \multicolumn{6}{|c|}{ Table 5: Question 5 } \\
\hline \multirow{3}{*}{ Valid } & & F & $\%$ & Valid \% & Cumulative \% \\
\cline { 2 - 6 } & Yes & 57 & 57.0 & 57.0 & 57.0 \\
\cline { 2 - 6 } & No & 43 & 43.0 & 43.0 & 100.0 \\
\cline { 2 - 6 } & Total & 100 & 100.0 & 100.0 & \\
\hline
\end{tabular}

Q5

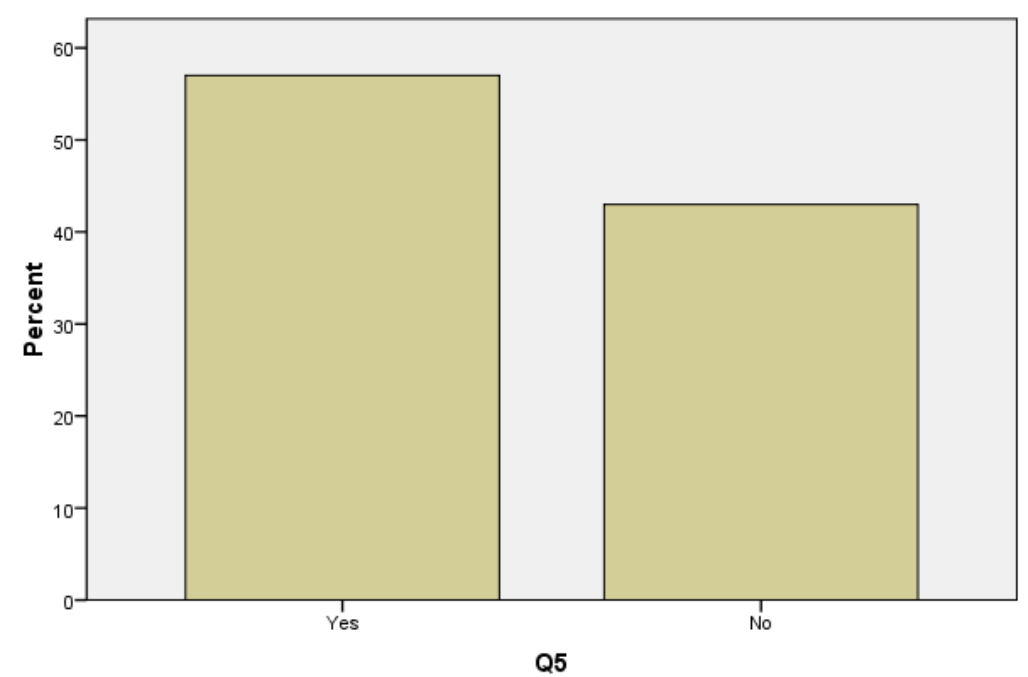

In whole, sample respondents $57 \%$ respondents are agreed that their supervisor support them and their endeavours, while 43 respondents said that their supervisor does not support them and their endeavours. 


\begin{tabular}{|l|l|l|l|l|l|}
\hline \multicolumn{7}{|c|}{ Table 6: Question 6 } \\
\hline \multirow{3}{*}{ Valid } & Salary structure & 14 & 14.0 & 14.0 & 14.0 \\
\cline { 2 - 7 } & Cash rewards & 16 & 16.0 & 16.0 & 30.0 \\
\cline { 2 - 7 } & Non-cash incentives & 21 & 21.0 & 21.0 & 51.0 \\
\cline { 2 - 7 } & Growth opportunities & 10 & 10.0 & 10.0 & 61.0 \\
\cline { 2 - 6 } & Performance system & 21 & 21.0 & 21.0 & 82.0 \\
\cline { 2 - 6 } & Supervisor Support & 18 & 18.0 & 18.0 & 100.0 \\
\cline { 2 - 6 } & Total & 100 & 100.0 & 100.0 & \\
\hline
\end{tabular}

Q6

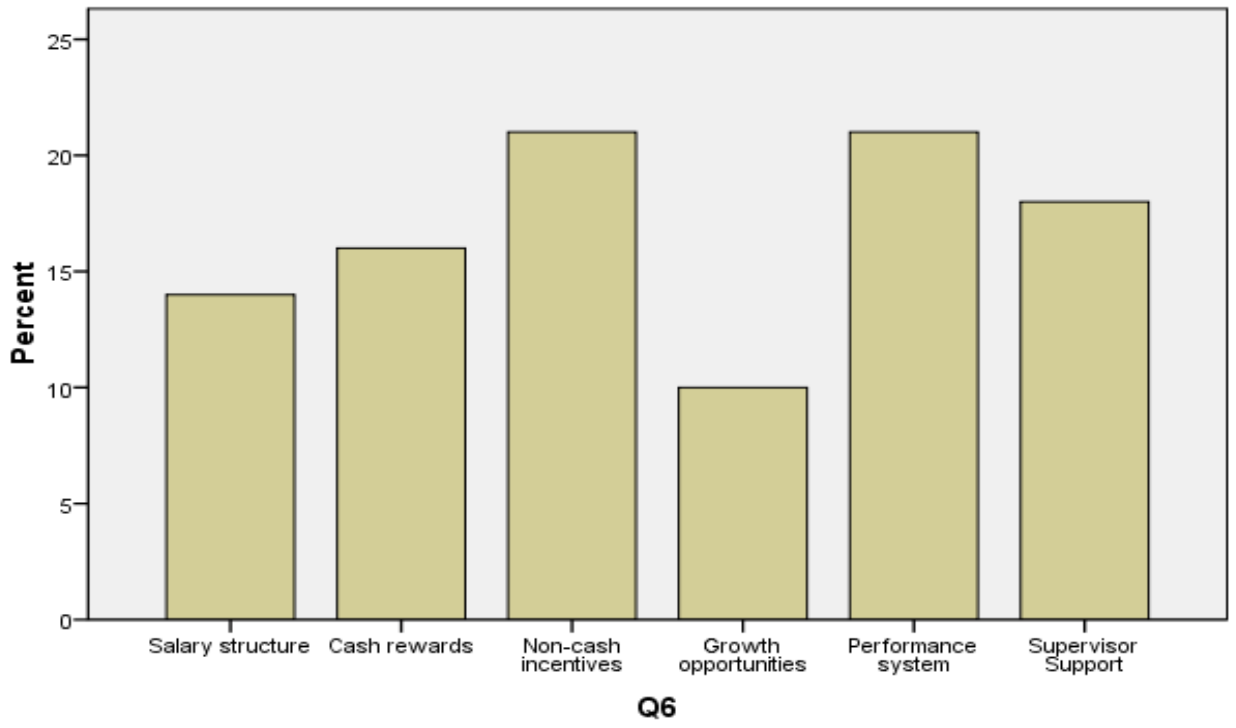

In response to question, what motivates you about your job? 14\% said salary structure, 16\% said cash rewards, $21 \%$ said non-cash incentives, and $10 \%$ said growth opportunities, $21 \%$ performance system, and $18 \%$ supervisor support.

\begin{tabular}{|l|l|l|l|l|l|}
\hline \multicolumn{6}{|c|}{ Table 7: Question 7 } \\
\hline \multirow{3}{*}{ Valid } & Always & 18 & 18.0 & 18.0 & 18.0 \\
\cline { 2 - 6 } & Often & 19 & 19.0 & 19.0 & 37.0 \\
\cline { 2 - 6 } & Sometimes & 21 & 21.0 & 21.0 & 58.0 \\
\cline { 2 - 6 } & Rarely & 23 & 23.0 & 23.0 & 81.0 \\
\cline { 2 - 6 } & Never & 19 & 19.0 & 19.0 & 100.0 \\
\cline { 2 - 6 } & Total & 100 & 100.0 & 100.0 & \\
\hline
\end{tabular}


Q7

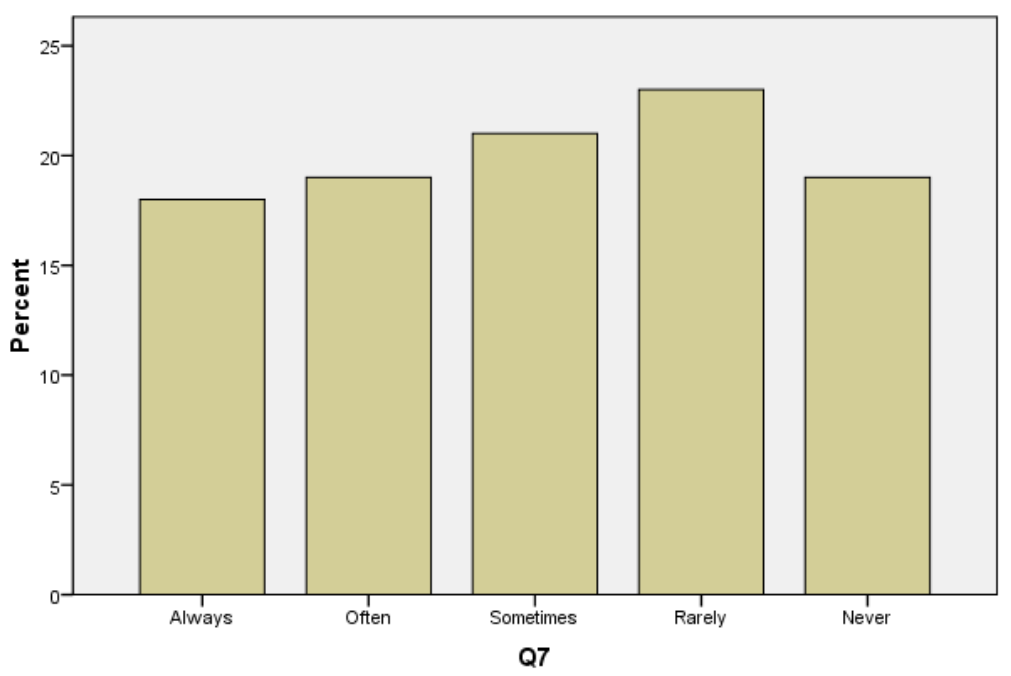

In response to question, your supervisor recognises the efforts of employees, $18 \%$ respondents marked always, 19\% marked often, 21\% marked sometimes, and 23\% marked rarely, and 19\% marked never.

\begin{tabular}{|l|l|l|l|l|l|}
\hline \multicolumn{7}{|c|}{ Table 8: Question 8 } \\
\hline \multirow{3}{*}{ Valid } & Strongly Agree & F & $\%$ & Valid \% & Cumulative \% \\
\cline { 2 - 6 } & Agree & 20 & 20.0 & 20.0 & 54.0 \\
\cline { 2 - 6 } & Disagree & 21 & 21.0 & 21.0 & 75.0 \\
\cline { 2 - 6 } & Strongly Disagree & 25 & 25.0 & 25.0 & 100.0 \\
\cline { 2 - 6 } & Total & 100 & 100.0 & 100.0 & \\
\hline
\end{tabular}

Q8

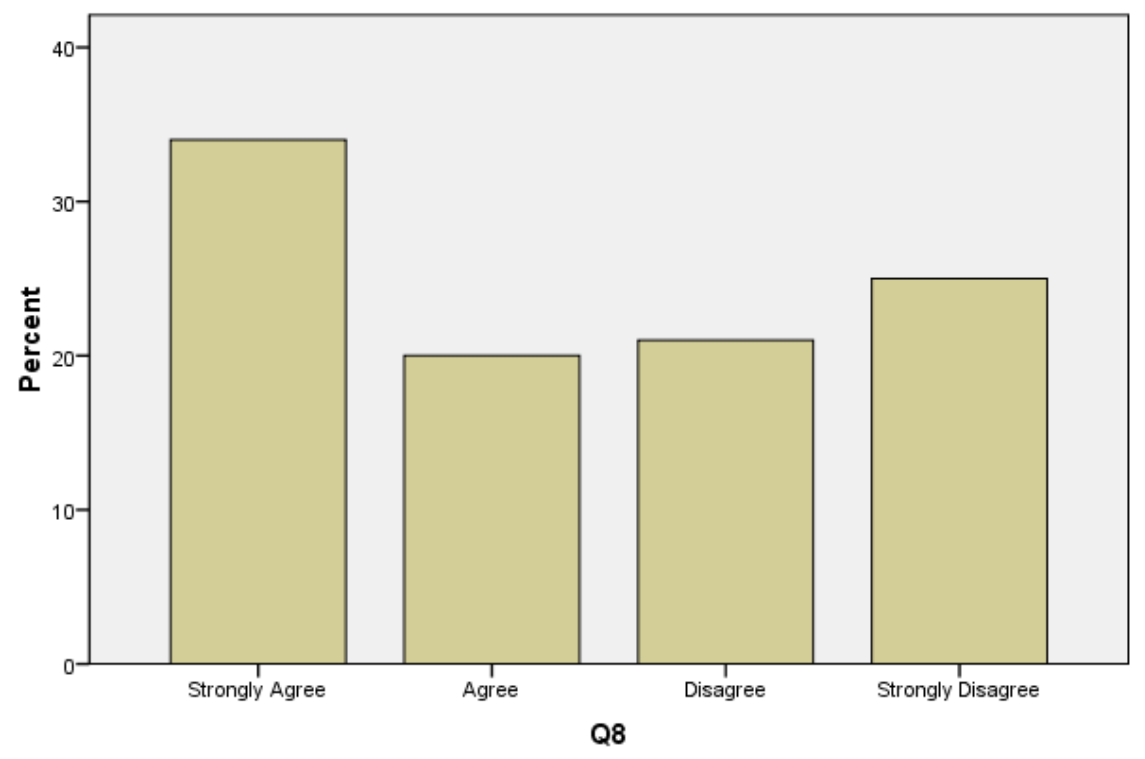


In response to question about working conditions, 34\% marked strongly agree $20 \%$ marked agree, $21 \%$ marked disagree, and 25\% marked strongly disagree.

\begin{tabular}{|l|l|l|l|l|l|}
\hline \multicolumn{7}{|c|}{ Table 9: Question 9 } \\
\hline & & F & $\%$ & Valid \% & Cumulative \% \\
\hline \multirow{3}{*}{ Valid } & Yes & 56 & 56.0 & 56.0 & 56.0 \\
\cline { 2 - 6 } & No & 44 & 44.0 & 44.0 & 100.0 \\
\cline { 2 - 6 } & Total & 100 & 100.0 & 100.0 & \\
\hline
\end{tabular}

Q9

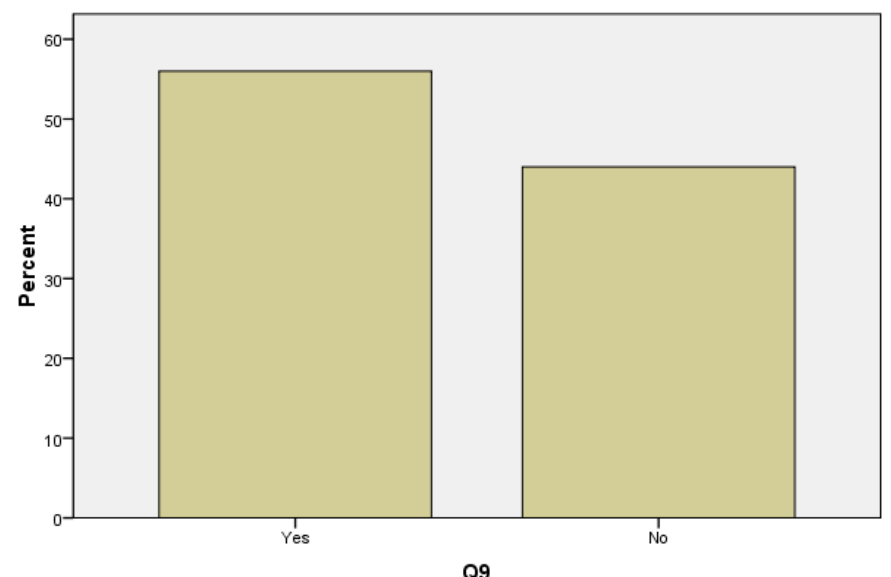

In response to discrimination of supervisor among employees, $56 \%$ respondents said that, their supervisor discriminate among employees, while $44 \%$ said that their supervisor do not discriminate among employees.

\begin{tabular}{|l|l|l|l|l|l|}
\hline \multicolumn{7}{|c|}{ Table 10: Question 10} \\
\hline \multirow{3}{*}{ Valid } & Strongly Agree & F & $\%$ & Valid \% & Cumulative \% \\
\cline { 2 - 6 } & Agree & 27 & 27.0 & 27.0 & 27.0 \\
\cline { 2 - 6 } & Disagree & 23 & 23.0 & 23.0 & 78.0 \\
\cline { 2 - 6 } & Strongly Disagree & 22 & 22.0 & 22.0 & 100.0 \\
\cline { 2 - 6 } & Total & 100 & 100.0 & 100.0 & \\
\hline
\end{tabular}

Q10

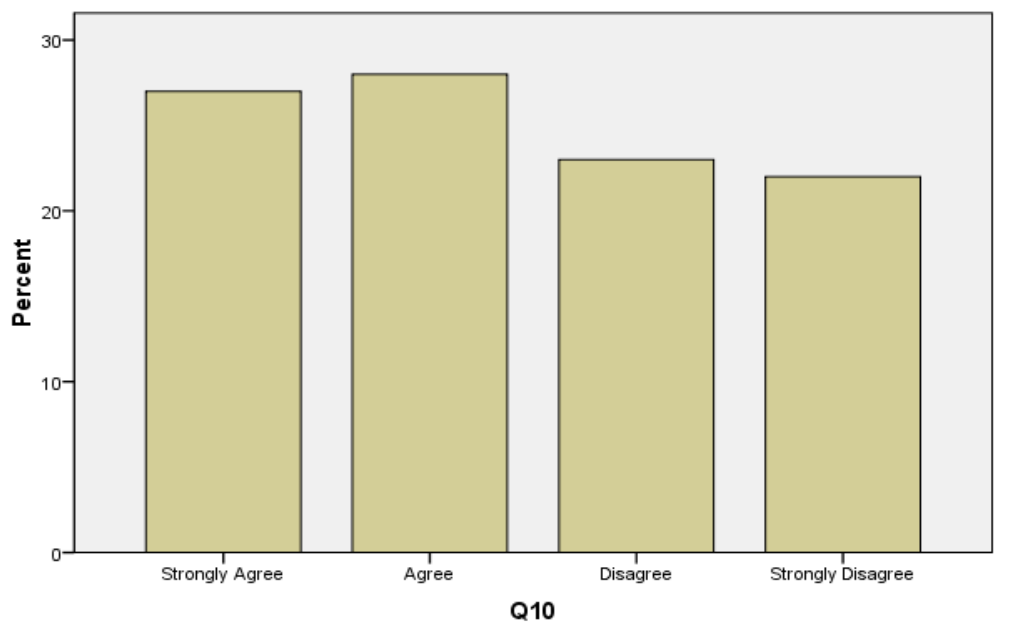


$27 \%$ respondent strongly agree with the statement that, the supervisor's support impacts the motivational level, while $28 \%$ respondents agree, $23 \%$ of the respondents disagree, and $22 \%$ respondents strongly disagree with the statement.

\begin{tabular}{|l|l|l|l|l|l|}
\hline \multicolumn{7}{|c|}{ Table 11: Question 11 } \\
\hline & & F & $\%$ & Valid \% & Cumulative \% \\
\hline Valid & Strongly Agree & 16 & 16.0 & 16.0 & 16.0 \\
\cline { 2 - 6 } & Agree & 29 & 29.0 & 29.0 & 45.0 \\
\cline { 2 - 6 } & Disagree & 25 & 25.0 & 25.0 & 70.0 \\
\cline { 2 - 6 } & Strongly Disagree & 30 & 30.0 & 30.0 & 100.0 \\
\cline { 2 - 6 } & Total & 100 & 100.0 & 100.0 & \\
\hline
\end{tabular}

Q11

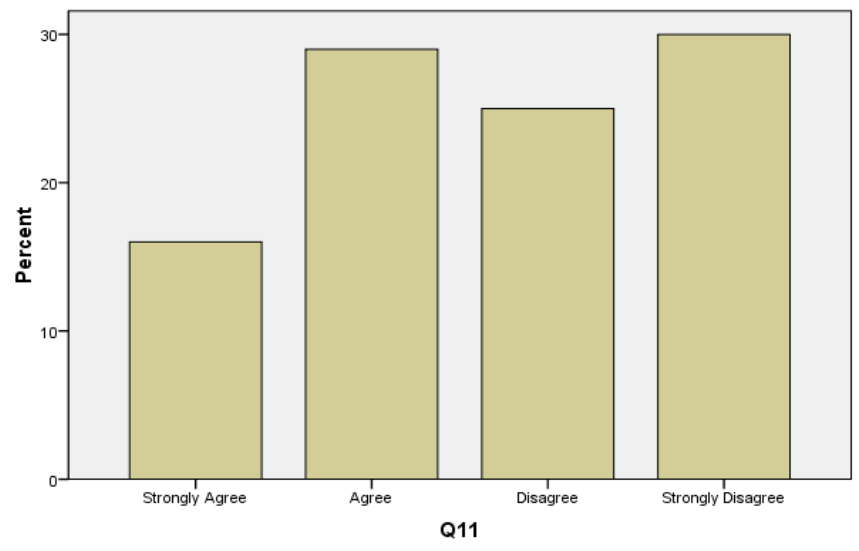

$16 \%$ respondent strongly agree with the statement that, the supervisor's support impacts the motivational level, while $29 \%$ respondents agree, $25 \%$ of the respondents disagree, and $30 \%$ respondents strongly disagree with the statement.

\begin{tabular}{|l|l|l|l|l|l|}
\hline \multicolumn{2}{|l}{ Table 12: Question 12 } \\
\hline & & $\mathrm{F}$ & $\%$ & Valid \% & Cumulative \% \\
\hline \multirow{3}{*}{ Valid } & Definitely & 24 & 24.0 & 24.0 & 24.0 \\
\cline { 2 - 6 } & Surely & 22 & 22.0 & 22.0 & 46.0 \\
\cline { 2 - 6 } & Not sure enough & 28 & 28.0 & 28.0 & 74.0 \\
\cline { 2 - 6 } & I don't Know & 26 & 26.0 & 26.0 & 100.0 \\
\cline { 2 - 6 } & Total & 100 & 100.0 & 100.0 & \\
\hline
\end{tabular}

Q12

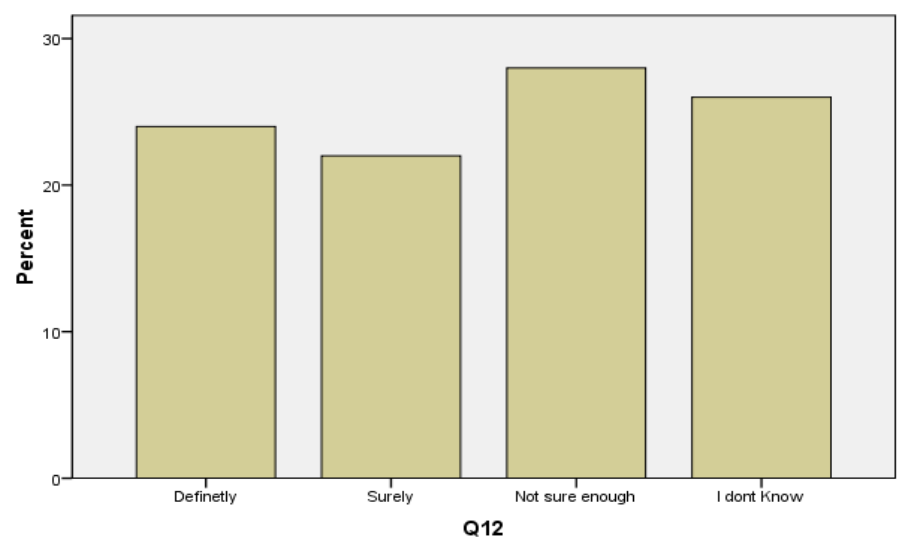


In response to question, when choosing a job, you would go for the one that pays higher salary; $24 \%$ respondents said they definitely go for it, while $22 \%$ said surely, $28 \%$ said not sure enough; and $26 \%$ said they don't know.

\begin{tabular}{|l|l|l|l|l|l|}
\hline \multicolumn{7}{|c|}{ Table 13: Question 13 } \\
\hline \multirow{3}{*}{ Valid } & Definitely & F & $\%$ & Valid \% & Cumulative \% \\
\cline { 2 - 6 } & Surely & 27 & 27.0 & 27.0 & 27.0 \\
\cline { 2 - 6 } & Not sure enough & 21 & 21.0 & 21.0 & 48.0 \\
\cline { 2 - 6 } & I dont Know & 32 & 32.0 & 32.0 & 100.0 \\
\cline { 2 - 6 } & Total & 100 & 100.0 & 100.0 & \\
\hline
\end{tabular}

Q13

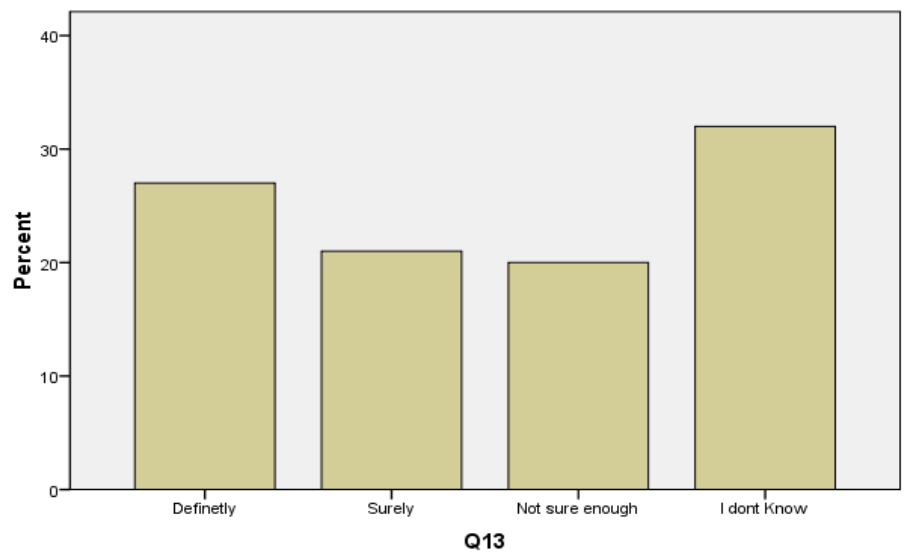

In response to question, when choosing a job, you would go for the one that pays higher salary; $27 \%$ respondents said they definitely go for it, while $21 \%$ said surely, $20 \%$ said not sure enough; and 32\% said they don't know.

\begin{tabular}{|c|c|c|c|c|c|}
\hline \multicolumn{6}{|c|}{ Table 14: Question 14} \\
\hline & & $\mathrm{F}$ & $\%$ & Valid \% & Cumulative \% \\
\hline \multirow[t]{5}{*}{ Valid } & Strongly Agree & 31 & 31.0 & 31.0 & 31.0 \\
\hline & Agree & 16 & 16.0 & 16.0 & 47.0 \\
\hline & Disagree & 26 & 26.0 & 26.0 & 73.0 \\
\hline & Strongly Disagree & 27 & 27.0 & 27.0 & 100.0 \\
\hline & Total & 100 & 100.0 & 100.0 & \\
\hline
\end{tabular}

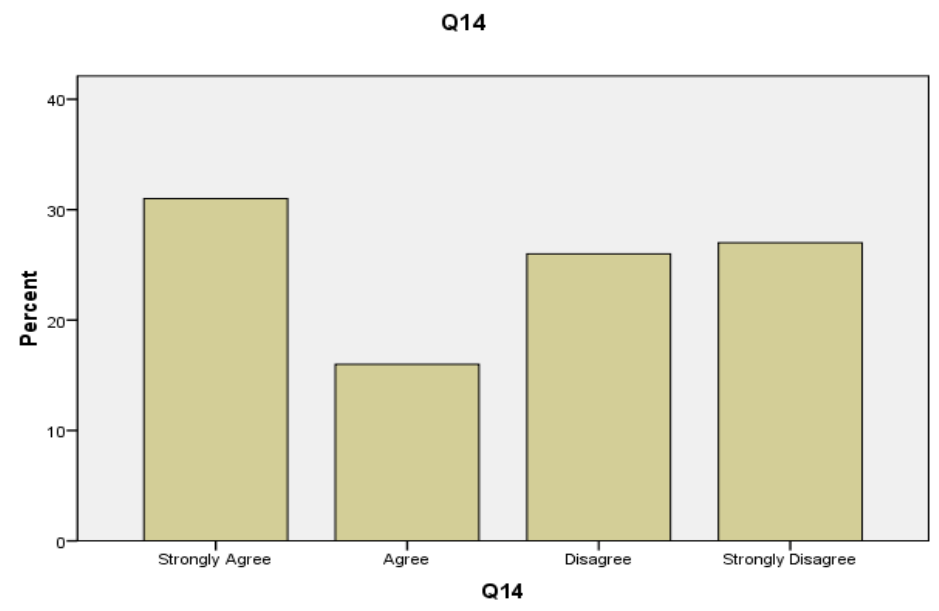


In response to question, does supervisor support important as motivation, $31 \%$ respondent strongly agree with the statement that, the supervisor's support impacts the motivational level, while $16 \%$ respondents agree, $26 \%$ of the respondents disagree, and $27 \%$ respondents strongly disagree with the statement.

\begin{tabular}{|l|l|l|l|l|l|}
\hline \multicolumn{7}{|c|}{ Table 15: Question 15 } \\
\hline & & $\mathrm{F}$ & $\%$ & Valid \% & Cumulative \% \\
\hline \multirow{3}{*}{ Valid } & Strongly Agree & 29 & 29.0 & 29.0 & 29.0 \\
\cline { 2 - 6 } & Agree & 28 & 28.0 & 28.0 & 57.0 \\
\cline { 2 - 6 } & Disagree & 23 & 23.0 & 23.0 & 80.0 \\
\cline { 2 - 6 } & Strongly Disagree & 20 & 20.0 & 20.0 & 100.0 \\
\cline { 2 - 6 } & Total & 100 & 100.0 & 100.0 & \\
\hline
\end{tabular}

Q15

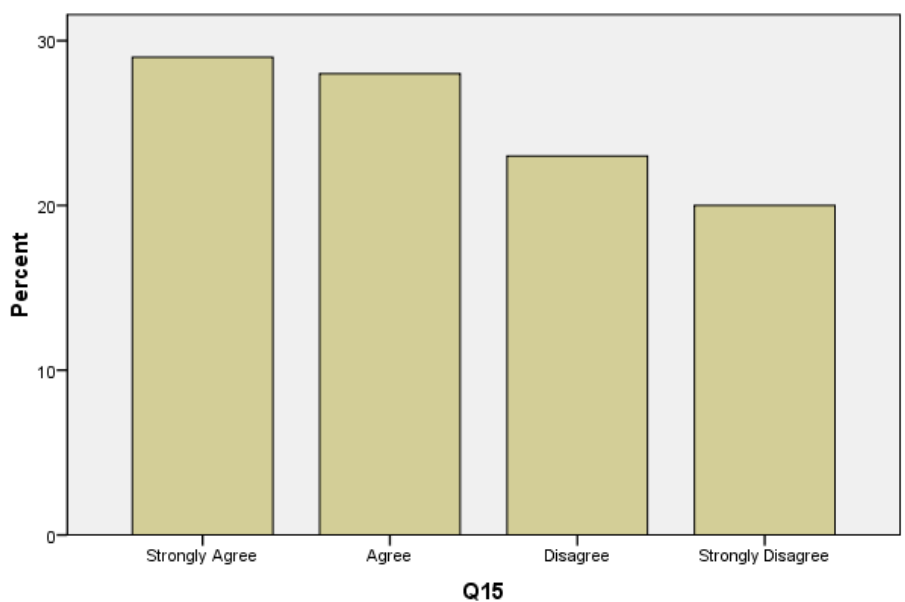

In response to question, does your supervisor think you are highly productive, $29 \%$ respondent strongly agree with the statement that, their supervisor think that they are highly productive, while $28 \%$ respondents agree, $23 \%$ of the respondents disagree, and $20 \%$ respondents strongly disagree with the statement.

Table 16: Frequencies

\begin{tabular}{|l|r|r|r|r|r|r|r|r|r|r|r|r|r|r|r|}
\hline & Q1 & Q2 & Q3 & Q4 & Q5 & Q6 & Q7 & Q8 & Q9 & Q10 & Q11 & Q12 & Q13 & Q14 & Q15 \\
\hline N Valid & 100 & 100 & 100 & 100 & 100 & 100 & 100 & 100 & 100 & 100 & 100 & 100 & 100 & 100 & 100 \\
\multicolumn{1}{c}{ Missing } & 0 & 0 & 0 & 0 & 0 & 0 & 0 & 0 & 0 & 0 & 0 & 0 & 0 & 0 & 0 \\
Mean & 1.50 & 2.52 & 1.47 & 1.63 & 1.43 & 3.62 & 3.06 & 2.37 & 1.44 & 2.40 & 2.69 & 2.56 & 2.57 & 2.49 & 2.34 \\
Median & 1.50 & 2.50 & 1.00 & 2.00 & 1.00 & 3.00 & 3.00 & 2.00 & 1.00 & 2.00 & 3.00 & 3.00 & 3.00 & 3.00 & 2.00 \\
Mode & 1 & 4 & 1 & 2 & 1 & $3^{\mathrm{a}}$ & 4 & 1 & 1 & 2 & 4 & 3 & 4 & 1 & 1 \\
Std. & .503 & 1.176 & .502 & .485 & .498 & 1.710 & 1.384 & 1.195 & .499 & 1.110 & 1.070 & 1.122 & 1.200 & 1.193 & 1.103 \\
Deviation & & & & & & & & & & & & & & & \\
Variance & .253 & 1.383 & .252 & .235 & .248 & 2.925 & 1.916 & 1.427 & .249 & 1.232 & 1.145 & 1.259 & 1.439 & 1.424 & 1.217 \\
Minimum & 1 & 1 & 1 & 1 & 1 & 1 & 1 & 1 & 1 & 1 & 1 & 1 & 1 & 1 & 1 \\
Maximum & 2 & 4 & 2 & 2 & 2 & 6 & 5 & 4 & 2 & 4 & 4 & 4 & 4 & 4 & 4 \\
\hline
\end{tabular}

a. Multiple modes exist. The smallest value is shown 
Table 17: Descriptive Statistics

\begin{tabular}{|l|c|r|r|r|r|}
\hline & $\mathbf{N}$ & Minimum & Maximum & Mean & Std. Deviation \\
\hline Q1 & 100 & 1 & 2 & 1.50 & .503 \\
\hline Q2 & 100 & 1 & 4 & 2.52 & 1.176 \\
\hline Q3 & 100 & 1 & 2 & 1.47 & .502 \\
\hline Q4 & 100 & 1 & 2 & 1.63 & .485 \\
\hline Q5 & 100 & 1 & 2 & 1.43 & .498 \\
\hline Q6 & 100 & 1 & 6 & 3.62 & 1.710 \\
\hline Q7 & 100 & 1 & 5 & 3.06 & 1.384 \\
\hline Q8 & 100 & 1 & 4 & 2.37 & 1.195 \\
\hline Q9 & 100 & 1 & 2 & 1.44 & .499 \\
\hline Q10 & 100 & 1 & 4 & 2.40 & 1.110 \\
\hline Q11 & 100 & 1 & 4 & 2.69 & 1.070 \\
\hline Q12 & 100 & 1 & 4 & 2.56 & 1.122 \\
\hline Q13 & 100 & 1 & 4 & 2.57 & 1.200 \\
\hline Q14 & 100 & 1 & 4 & 2.49 & 1.193 \\
\hline Q15 & 100 & 1 & 4 & 2.34 & 1.103 \\
\hline Valid N (listwise) & 100 & & & & \\
\hline
\end{tabular}

\section{Regression Analysis}

\begin{tabular}{|l|c|r|r|r|}
\hline \multicolumn{5}{|c|}{ Table 18: Model Summary } \\
\hline Model & $\mathrm{R}$ & R Square & Adjusted R Square & Std. Error of the Estimate \\
\hline 1 & $.79^{\mathrm{a}}$ & .76 & .74 & 1.35795 \\
\hline a. Predictors: (Constant), Employees Performance \\
\hline
\end{tabular}

The value of $r$ square 0.76 shows that there is positive strong relationship between the variables. Based on which it can be said that there is a significant impact of Employees Performance on Success of an Organization.

\begin{tabular}{|c|c|c|c|c|c|c|}
\hline \multicolumn{7}{|c|}{ Table 19: ANOVA $^{\mathrm{a}}$} \\
\hline \multicolumn{2}{|c|}{ Model } & Sum of Squares & df & Mean Square & $\mathrm{F}$ & Sig. \\
\hline \multirow[t]{3}{*}{1} & Regression & 1.125 & 1 & 1.125 & .610 & $.17^{b}$ \\
\hline & Residual & 180.715 & 98 & 1.844 & & \\
\hline & Total & 181.840 & 99 & & & \\
\hline \multicolumn{7}{|c|}{ a. Dependent Variable: how do you rate the brand on the following attributes } \\
\hline \multicolumn{7}{|c|}{ b. Predictors: (Constant), Employees Performance } \\
\hline
\end{tabular}

The value of sig closer to zero suggests that the relationship between the variables is significant.

\section{CONCLUSION AND RECOMMENDATIONS}

In this era of tough competition it is very important for organization to maintain and improve employees' performance on continual basis to remain at higher productivity. Organizations in Saudi Arabia should also implement strong indicators of increasing employee performance as it has now become a very important factor in success of organizations according to their culture. It keeps employees motivated and connected with the goals of their organization. It also creates trust and responsibility in employees about their management and job they hold. Furthermore, the analysis outcome suggests that success of a company do depend on employee performance. The purpose of selecting frequency distribution was simply to gather the view point of people working in Jeddah- Saudi Arabia regarding the success of organization. This gathering of primary data along with reviewing the existing literature enables the researcher 
to prove that success of a company is a result of significant employee performance. This study is performed and proved in Jeddah Saudi Arabia. As per the consent of the respondents their names will not be disclosed.

This study is about the impact of employees' performance on success of the organization. It also examines if employee productivity is affected by their performance management. And to what extent these factors affect each other. According to previous studies about the implementation of different pay models to increase employees' motivation, this study show more exact results about how much impacting can any of the model be. It also discusses the work related efforts of employees, performance appraisals, opportunities for development and their effects. The appraisal should be on the basis of the performance so that it keeps the performance on right path towards the achievement of organizational goals. An employee can never be productive for his/her respective organization if he has not been improved as a person wholly as well as his job related skills. Although motivation keep employees retained in the organization but in today's world only monetary side motivation can not be sufficient to retain an employee. Motivation is the combination of monetary rewards as well as other corporate factors. A manager's role has now become more challenging in terms of identifying what culture organization should adopt and what it should not. If the firm has poor environment, there are likely chances of an employee to switch the organization to get better environment. Even he gets less wages or monetary reward.

It is priority of every organization to keep its employees' performance at highest level. In order to get this desired outcome from employees it should work on employees' job satisfaction. It is certain that job satisfaction is affected by several factors. In fact, those factors may have different impact on different employees. One may get motivated by monetary reward while other may seek for recognition and acknowledgement. If the organization successfully convey the message of how important the employees are for the firm, this will create a win-win situation for both firm and employees.

Employee satisfaction can be a crucial factor to consider. If employee is not satisfied with his/her job he/she is more likely to leave the organization. This will result in higher turnover for the organization. It will also increase cost of hiring new employees as well as leaves a competence gap from the time ex employee leaves till new one is hired. Along with that employee takes his/her expertise and experience with him to other organization. This will affect the bottom line of the organization. Employees can also be a source of bad word of mouth because of their dissatisfactory experience. This can hit the goodwill and reputation of the firm very badly and can be very critical if not treated properly.

\section{RECOMMENDATIONS}

Employees are said to be true asset for the organization. If treated properly can be a very strong source of competitive advantage for the organization which can be unbeatable. Employees if not treated effectively and efficiently can also cause huge loss for the organization. To identify the improvement needed areas in employee's training and development as well as to retain those different practices of Human Resource Management can be followed efficiently. Many non-profit and profit earning firms were studied which proved that HRM practices such as recruitment and selection and training and development can cause increase in performance of employees.

HRM is not only source of hiring and attracting employees but also developing them to its maximum level to get higher performance. It can also lead the organization to more stable level 
if appropriate practices are followed. HRM identifies suitable skills employee posses and polish them to get maximum outcome. Providing equal opportunities keep employees highly satisfied with their job and keep their performance and organizational goals well aligned.

\section{REFERENCES}

Abe, H., (1983), "A cross-culture confirmation of the dimensions of intercultural effectiveness", International Journal of Intercultural Relations, 7(3), pp.66-67

Adcock, R. Collier, D. (2001), "Measurement validity": A shared standard for qualitative and quantitative research", American Political Science Review vol. 95, p. 529-546

Adler, N. (1991), International dimensions of organisational behaviour, Boston, WS-Kent, pp.10-11

Alderfer, C. (2002), Existence, relatedness, and growth, Human needs in organizational settings, Dublin, Cambridge University Press, pp.44-45

Ali, A. (1995), "Expatriates and host country nationals: managerial values and decision styles", Leadership and Organisation Development Joumal, 16(6), pp.85-86

Arthur, P. (2008), "Attitudes in and Around Organizations" Thousand Oaks, CA: Sage, p.32-64.

Baldwin, T. (1988), "Transfer of training, a review and directions for future research", Personnel Psychology, 41(2), pp.63-64

Baliga, M. (1985), “Multinational Corporate Policies for Expatriate Managers, Selection, Training,

Evaluation", Sam Advanced Management Journal, 90(2), pp.74-75

Bandura, A. (1997). Self-efficacy, The exercise of control, New York, W. H. Freeman and Company, pp.25-26

Bell, A. (1992). Business communication, Cincinnati, South Western Press, pp.78-79

Bennett A. (2004) "Case study methods" : Design, use and comparative advantages . In Sprinz D. F. WolinskyNahmias Y. (Eds.), Models, numbers and cases: Methods for studying international relations. p. 19-55.

Berg, B. (2001), Qualitative Research Methods for the Social Science, New York, Pearson Education, pp.52-53

Bhagat, R. (1996), Cross-Cultural Training in Organisational Contexts, Thousand Oaks, Sage, pp.89-90

Bird, A. (2002), Encyclopedia of Japanese Business and Management, Dublin, Routledge, pp.33-34

Black, J. (1990), "The relationship of personal characteristics with adjustment of Japanese expatriate managers", Management International Review, 30(4), pp.119-120

Bond, M. (1991), "The process of enhancing team competence in Hong Kong organisations", International Journal of Intercultural Relations, 16((4), pp.395-396

Branine, M. (1996), "Observations on training and management development in the People's Republic of China", Personnel Review, 25(1), pp.25-39

Branine, M. (2005), "Cross-cultural training of managers, An evaluation of a management development programme for Chinese managers", Journal of Management Development, 24(5), pp.459-460

Briscoe, D. (2004), International Human Resource Management, Dublin, Routledge, pp.85-86

Brown, A. (1998), Organisational Culture, Dublin, Prentice Hall, pp.71-72

Brown, G. (2006), "Keeping Score: Using the Right Metrics to Drive World-Class Performance". New York: Quality Resources, p. 21-43. 
Caligiuri, P. (2004). Performance measurement in a cross-national context: evaluating the success of global assignments, New Jersey, Lawrence Erlbaum Associates Publishers, pp.48-49

Cameron, J. (2004), Reinforcement, reward, and intrinsic motivation, A meta-analysis. Review of Retail Management, 74(8), pp.33-34

Caruth, D. (2008), Managing Compensation, A Handbook for the Perplexed, Dublin, Oxford University Press, pp.10-11

Chau, W. (1984), "A study of job satisfaction of workers in local factories of Chinese, Western, and Japanese ownership", Hong Kong Mangers, 20(5), pp.59-60

Chen M (2004) Asian Management Systems, Dublin, Thomson, pp.63-64

Church, A. (1982). "Sojourner adjustment", Psychological Bulletin, 9(3), pp.54-55

Colquitt, J. A., LePine, J. A., \& Wesson, M. J. (2011). “Organizational behavior: improving performance and commitment in the workplace (2nd ed.) [Chapter 2\&4]." New York, NY: McGraw-hill Irwin., p. 105-108.

Costa, P. (1987), "Validation of the five-factor model of personality across instruments and observers", Journal of Personality and Social Psychology, 52(4), pp.81-90

Creswell J. W. (2009) "Research Design": Qualitative and quantitative approaches (3rd ed.), Thousand Oaks, CA: Sage, pp: 81-120

Cui, G. (1991), "Testing the construct validity of intercultural effectiveness", International Journal of Intercultural Relations, 15(3), pp.227-228

Dalal, R. (2008), Motivation, A dynamic perspective of the criterion for work motivation, Past, present, and future, Dublin, Routledge, pp.63-64

Davies, M., (2007), "Doing a successful research project: Using qualitative or quantitative methods," New York, NY: Palgrave Macmillan, p. 14-25

Drucker, P. F. (2007), The effective executive, Dublin, Butterworth-Heinemann, pp.36-37

Dunbar, E. (1992), "Adjustment and satisfaction of expatriate managers in US", International Journal of Intercultural Relations, 16(3), pp.15-16

Early, P. (1987), "Intercultural training for managers, a comparison of documentary and interpersonal methods", Academy of Management Journal, 30(4), pp.685-686

Eisenberger, R. (2007), "Pay for performance increases or decreases self-determination and intrinsic motivation", Journal of Personality and Social Psychology, 88(5), pp.26-27

Evans, P. (2002), The global challenge: Frameworks for international human resource management, Boston, McGraw-Hill, pp.89-90

Finney, M. (1988), "Integrating academic and organisational approaches to developing the international manager", Journal of Management Development, 7(6), pp.16-17

Fogelman, K. , and Comber, C. (2007). "Surveys and sampling". In A. R. J. Briggs, ed. and M. Coleman (Eds.), Research methods in educational leadership and management (2nd ed.) p. 125-141

Ford, D. (2003), Managing Business Relationships, Chichester, Wiley, pp.25-26

Fowler, F. (2002) "Survey Research Methods" Thousand Oaks, p.36-68

Giddens, A. (1989), Sociology, Greenwich, JAI Press, pp.57-58

Griggs, L. (1985), Going International, New York, Plume, pp.12-13 
Gupta, A. (2002), "Cultivating a global mindset", The Academy of Management Executive, 16(5), pp.116-126

Guthrie, G. (1975), A behavioural analysis of cultural learning, Cross-cultural perspectives on learning, New York, Wiley, pp.37-38

Handlogten, G. (2007), “Compensating Sales Personnel”, The Irish Salesman, 89(3), pp.15-16

Handy, C. (2003), Understanding Organisations, Dublin, Penguin, pp.71-72

Harris, H. (2003), International Human Resource Management, Dublin, CIPD, pp.44-45

Harrison, J. (1994). “Developing successful expatriate managers, A framework for the structural design and strategic alignment of team training programmes", Human Resource Planning, 90(2), pp.12-13

Hays, R. (1974), "Expatriate selection: insuring success and avoiding failure", Journal of International Business Studies, 4(1), pp.36-37

Henry, J. (2001), Creativity and Perception in Management, Dublin, Sage, pp.96-97

Herzberg, F. (1959), The Motivation to Work, Dublin, John Wiley \& Sons, PP.47-48

Herzberg, F. (2008), “Motivating employees”, England Business Review, 86(8), pp.53-54

Higgins, J. M. (1994), The management challenge, Dublin, Macmillan, pp.74-75

Ilaffaldano, M. T., \&Muchinsky, P. M. (1985). "Job satisfaction and job performance: a meta-analysis."

Psychological Bulletin, vol. 97(2), p. 251-273.

Jackson T (2002), International HRM, A Cross-Cultural Approach, Dublin, Sage, pp.25-26

Jackson, T. (2002), "The management of people across culture: valuing people differently", Human Resource Management, 41(4), pp.71-72

Johnson, G. (1993), Exploring Corporate Strategy, Text and Cases, Dublin, Prentice Hall, pp.85-86

Jones, M. (2006) “Which is a Better Predictor of Job Performance: Job Satisfaction or Life Satisfaction?" Institute of Behavioural and Applied Management, p. 20-28.

Judge, T. A., Thoresen, C. J., Bono, J. E., \& Patton, G. K. (2001). "The job satisfaction-job performance relationship: qualitative and qualitative review." Psychological Bulletin, vol. 127(3), p. 376-407.

Kealy, D. (1996), "The effectiveness of cross culture training for expatriates, an assessment of the literature on the issue", International Journal of Intercultural Relations, 20(4), pp.141-142

Kinicki, A.J. Prussia, G.E. Wu B. and McKee-Ryan, F.M. (2004), "A covariance structure analysis of employees' response to performance feedback", Journal of Applied Psychology 89, Pp. 1057-1069

Kopp, R. (2001), "Why is it so difficult to tell what a Japanese person is thinking?" Japan Close-Up, 85(3), pp.30-31

Kraemer, H. K. , and Thiemann, S. (1987). "How many subjects? Statistical power analysis in research". Newbury Park, CA: Sage.

Lapierre, L. M., \& Hackett, R. D. (2007) "Trait conscientiousness, leader-member exchange, job satisfaction and Organizational citizenship behavior: a test of inegrative model." Journal of Occupational and Organizational Psychology, vol. 80, p. 539-554.

Leonard, N. (2006), "Work motivation", Human Relations, 59(12), pp.98-99

Likert, R. (1967), The human organisation, its management and value, Dublin, McGraw-Hill Publishers, pp.8586 
Locke, E.A. and P. Latham (2008), "A theory of goal setting and task performance" Englewood Cliffs, NJ: Prentice Hall, Pp. 198

Locke, E.A., D.B. Feren, V.M. McCaleb, K.N. Shaw, and A.T. Denny (2006), "The relative effectiveness of four methods of motivating employee performance", New York: Wiley: Pp. 363-388

Luthans (2004), “Organization Behavior”, People Post Press, Pp. 98

Maslow, A. (1943), “A theory of human motivation", Psychological Review, 50(3), pp.37-38

Maslow, A. H. (1943), “A Theory of Human Motivation", Psychological Review, 50(1), pp.39-40

McCrae, R. (1989), "More reasons to adopt the five-factor model”, American Psychologist, 44(8), pp.451-452

Mead, R. (2009), International Management, Chichester, John Wiley \& Sons, pp.85-86

Meindl, J. (1997), "Testing the affects of vertical and horizontal connectivism: a study of reward allocation preferences in China", Journal of Cross-Cultural Psychology, 28 (1), pp.44-47

Mendenhall, M. (2002), Employee development and expatriate assignments, Dublin, Blackwell Publishers, pp.41-42

Moran, R. (1991), Managing cultural differences, Houston, Gulf Publishing, pp.117-118

Morgan, G , Gliner, J. A. , and Harmon, R. J. (2006) "Sampling and population external validity". In Understanding and evaluating research in applied and clinical settings. p. 122-128.

Mullins, L. (2005), Management and Organisational Behaviour, Harlow Prentice Hall, pp.74-75

Munz (2001), "Effectiveness of a Comprehensive Worksite Stress Management Program: Combining

Organizational and Individual Interventions". International Journal of Stress Management, Pp. 49- 60

Rainey, H. (2007), Reward preferences among retail supervisors, In search of the service ethics, Irish Review of Retail Administration, 31(9), pp.28-29

Richards, D. (1996), "Strangers in a strange land: expatriate paranoia and the dynamics of exclusion", International Journal of Human Resource Management, 7(2), pp.553-554

Robie, C. (2001), "A meta-analysis of the effects of team training in expatriate performance and adjustment", International Journal of Training and Development, 5(1), pp.112-113

Rugimbana, R. (2003), Cross-cultural Marketing, Dublin, Thomson, pp.96-97

Rummler, G. (2006), Improving performance with Motivation, Dublin, Wiley Press, pp.28-29

Ryan, R. (2000), "Self-determination theory and the facilitation of intrinsic motivation, social development, and well-being", Irish Psychologist, 55(2), pp.68-69

Salant, P and Dillman, D (1994) "How to Conduct Your Own Survey", New York: Wiley.

Salas, E. (2001), "The science of training, A decade of progress", Annual Review of Psychology, 52(7), pp.471472

Salgado, J. (1997), "The five-factor model of personality and job performance in the European Community", Journal of Applied Psychology, 82(10), pp.30-31

Saunders, M. et al. (2007) Research Methods for Business Students (4th ed), p.41-56

Schaap, A. (1994), "Outsiders in the Middle Kingdom, Expatriate Managers in Chinese - Western Joint Ventures", European Management Journal, 12(2), pp.147-148

Schuler, S. (2004), International Human Resource Management, New York: Prentice Hall, pp.28-29 
Sekaran, (2000), Research Methods for Business with Software Cd- Rom Set, John Wiley \& Sons Canada. pp.89-114

Senécal, C. (2007), "Proximal job characteristics, feelings of empowerment, and intrinsic motivation: A multidimensional model", Journal of Applied Social Psychology, 37(12), pp.22-23

Shah, K. (2008), Theories of Motivation, Dublin, Sage Publishers, pp.36-37

Spector, P. E. (2006). "Industrial and Organizational Psychology: research and practice (4th ed.)" [chapter 9 \& 10]. Hoboken, NJ: John Wiley \& Sons, Inc., p. 49, 216, 245.

Sudman, S. (1976) "Applied Sampling". New York: Academic Press. p.78

Thomas, K. (2006), Intrinsic motivation at work, Building energy and commitment, Dublin, Oxford University Press, pp.56-57

Trompenaars, F. (1997), Riding the Waves of Culture, Dublin, Nicholas Brealey, pp.65-66

Weisbord, M. (2007), Productive workplaces, Organising and managing for dignity, meaning, and community, Leeds, Leeds University Press, pp.89-90

White, R. (2008), "Motivation reconsidered, the concept of competence", Psychological Review, 116(5), pp. $29-30$

Wright, P. (2004), "Human resources and sustained competitive advantage: a resource-based perspective", International Journal of Human Resource Management, 25(10), pp.55-56 


\section{Questionnaire}

\section{APPENDIX}

Name:

Q1: Your gender

○ Male

○ Female

Q2: You belong to age group
○ 21-30
○ $31-40$
○ $41-50$
○ $51-60$

Q3: Are you employed in retail sector firm
○ Yes
○ No

Q4: Are you satisfied with the working environment?
o Yes
○ No

Q5: Does your supervisor support you and your endeavours?
○ Yes
○ No

Q6: What motivates you about your job?
- Salary structure
- Cash rewards
- Non-cash incentives
○ Growth opportunities
- Performance system
- Supervisor Support

Q7: Do you think that your supervisor recognises the efforts of employees?
- Always
- Often
- Sometimes
○ Rarely
o Never

Q8: Do you think that working conditions in the firm are good?
○ Strongly agree
- Agree
○ Disagree
- Strongly disagree

Q9: Is there any discrimination on part of supervisor among employees?
○ Yes
○ No 
Q10: The supervisor's support impacts motivational level
○ Strongly agree
○ Agree
- Disagree
- Strongly disagree

Q11: Individual differences are also important factor in motivation
○ Strongly agree
- Agree
- Disagree
○ Strongly disagree

Q12: When choosing a job, you would go for the one that pays higher salary
○ Definitely
- Surely
○ Not sure enough
○ I don't know

Q13: When choosing a job, you would go for the one that recognises your efforts
○ Definitely
- Surely
○ Not sure enough
- I don't know

Q14: Supervisor's support is as important as motivation
- Strongly agree
- Agree
- Disagree
- Strongly disagree

Q15: Does your supervisor think you are highly productive?
- Strongly agree
- Agree
○ Disagree
○ Strongly disagree 